Jes Focus Issue on Progress in Molten Salts and lonic Liquids

\title{
Vanadium Speciation in Fused Alkali Chlorides
}

\author{
I. B. Polovov, ${ }^{a, *, z}$ M. V. Chernyshov, ${ }^{a}$ V. A. Volkovich, ${ }^{a, *}$ B. D. Vasin, ${ }^{a}$ and T .R. Griffiths ${ }^{b}$ \\ ${ }^{a}$ Department of Rare Metals and Nanomaterials, Institute of Physics and Technology, Ural Federal University, \\ Ekaterinburg 620002, Russia \\ ${ }^{b}$ Energy Process Developments Ltd., London SE1 4AG, United Kingdom
}

\begin{abstract}
Electronic absorption spectra of vanadium ions were recorded between 450 and $750^{\circ} \mathrm{C}$ in $3 \mathrm{LiCl}-2 \mathrm{KCl}, \mathrm{NaCl}-\mathrm{KCl}$ and $\mathrm{NaCl}-2 \mathrm{CsCl}$ based melts. Analysis of the spectra showed that vanadium in the oxidation states of +2 and +3 is present in the melts as complex chloro-ions. Vanadium(II) can form the complex ions in octahedral and tetrahedral coordination, the latter being favored by higher temperatures. Only six-coordinated V(III) ions were observed. Vanadium in the oxidation state of +4 can be present in chloride melts only in the form of vanadyl-based oxochloro-species. Main spectroscopic parameters of vanadium complex ions were determined. Electronic absorption spectroscopy was also applied for studying a variety of the red-ox processes in vanadium containing melts including electrochemical oxidation and reduction of various species, and reaction of vanadium containing melts with oxygen. (c) The Author(s) 2017. Published by ECS. This is an open access article distributed under the terms of the Creative Commons Attribution 4.0 License (CC BY, http://creativecommons.org/licenses/by/4.0/), which permits unrestricted reuse of the work in any medium, provided the original work is properly cited. [DOI: 10.1149/2.0201708jes] All rights reserved.

(c) BY
\end{abstract}

Manuscript submitted February 15, 2017; revised manuscript received March 24, 2017. Published May 6, 2017. This paper is part of the JES Focus Issue on Progress in Molten Salts and Ionic Liquids.

Vanadium has many attractive properties including high creep strength, excellent strength-to-weight ratio, resistance to corrosion, low neutron cross-section, high thermal conductivity, etc. ${ }^{1}$ Due to these unique set of properties vanadium is used in non-ferrous and ferrous metallurgy as a component of titanium-based alloys for the aerospace industry and for manufacturing special steels. ${ }^{2,3}$ High-purity vanadium metal is required for manufacturing alloys for nuclear fusion applications, superconducting and hydrogen-storage materials. ${ }^{4-6}$ Vanadium on industrial scale is produced by aluminum or carbon reduction of oxides or magnesium reduction of vanadium chlorides. ${ }^{7-9}$ To obtain the high-purity metal, the crude material is refined by vacuum melting or electrolysis in molten chlorides. ${ }^{10}$ Electrolytic refining is effective in removing most of metallic and nonmetallic impurities, i.e. aluminum, magnesium, iron, carbon, nitrogen, oxygen, silicon, etc. Understanding vanadium speciation in chloride melts is essential for designing or optimizing an industrial electrochemical process.

Vanadium is a polyvalent metal and, as for many d-element ions with partially filled d-orbitals, electronic absorption spectroscopy was employed for characterization of vanadium species in fused salts. In molten salts vanadium is capable of forming the ions containing the element in oxidation states $+2,+3,+4$ and +5 . First electronic absorption spectra (EAS) of vanadium-containing melts were recorded over a half of a century ago in $\mathrm{LiCl}-\mathrm{KCl}$ eutectic, $\mathrm{KAlCl}_{4}$ and $\mathrm{Cs}_{2} \mathrm{ZnCl}_{4},{ }^{11-14}$ followed by KSCN based melts. ${ }^{15,16}$ Subsequent studies included other alkali chloride mixtures. ${ }^{17-20}$ Analysis of the data present in the literature showed that there is a considerable controversy about the stable oxidation states of vanadium and the coordination geometry of its complex ions in the lower oxidation states in molten alkali chlorides. Vanadium in the oxidation states +2 and +3 was said to form complex ions where the metal is coordinated to six or four anions in octahedral or tetrahedral geometry, respectively. In the higher oxidation states, +4 and +5 , vanadium in the melts is present in the form of oxygen-containing ions. Gruen and $\mathrm{McBeth}^{13,14}$ suggested an octahedral-tetrahedral equilibrium, $\mathrm{VCl}_{6}{ }^{\mathrm{n}-} \leftrightarrow \mathrm{VCl}_{4}{ }^{(\mathrm{n}-2)-}(\mathrm{n}=4$ or 3 ) for $\mathrm{V}$ (II) and $\mathrm{V}$ (III) in molten $3 \mathrm{LiCl}-2 \mathrm{KCl}$ eutectic, and reported that the equilibrium is shifted to the right with increasing temperature..$^{13,14}$ Spectroscopic studied performed in $\mathrm{NaCl}-\mathrm{KCl}$ based melts at $750^{\circ} \mathrm{C}$ showed that the oxidation state of +3 was the most stable. ${ }^{19}$ Addition of excess vanadium metal or another suitable reducing metal (e.g., silver) to a $\mathrm{V}$ (III)-containing melts resulted in reduction of $\mathrm{V}$ (III) to

*Electrochemical Society Member.

${ }^{\mathrm{z}}$ E-mail: polovov_ilya@mail.ru
V(II). Vanadium(II) chloro-ions partially reacted with silica (the material of the experimental cell) forming an oxygen-containing phase insoluble in the melt. The reaction of V(II)-containing melts with oxygen also led to precipitation of insoluble vanadium oxo-species. Exposure of $\mathrm{NaCl}-\mathrm{KCl}-\mathrm{VCl}_{3}$ melts to an oxygen containing atmosphere did not change total vanadium concentration in the melt but $\mathrm{VCl}_{6}{ }^{3-}$ ions were oxidized to $\mathrm{VOCl}_{4}{ }^{2-} \cdot{ }^{19,20}$

Chlorination of metallic vanadium by chlorine in a $\mathrm{NaCl}-\mathrm{KCl}$ melt produced a mixture of vanadium chlorides, the composition of the products depended on excess of $\mathrm{Cl}_{2}$ used. ${ }^{19}$ Vanadium(II) and (III) chloro-species were formed at low $\mathrm{Cl}_{2}$ flow rates. Vanadium(IV) chloride formation was observed when considerable excess $\mathrm{Cl}_{2}$ was used, and most of vanadium sublimed from the melt in the form of volatile $\mathrm{VCl}_{4}$.

Anodic dissolution of vanadium in $\mathrm{LiCl}-\mathrm{KCl}, \mathrm{NaCl}-\mathrm{CsCl}$ and $\mathrm{NaCl}-\mathrm{KCl}$ based melts at $450-750^{\circ} \mathrm{C}$ resulted in formation of vanadium(II) chloro-ions. ${ }^{20}$ Dissolution of vanadium dichloride in molten alkali chlorides produced a mixture of $\mathrm{V}(\mathrm{II})$ and $\mathrm{V}(\mathrm{III})$ chloro-species due to partial disproportionation of $\mathrm{VCl}_{2}$ to $\mathrm{VCl}_{3}$ and vanadium metal. ${ }^{20}$ Vanadium(III) containing melts were obtained upon dissolving $\mathrm{VCl}_{3} \cdot{ }^{20}$ Electrochemical (potentiostatic) reduction of $\mathrm{V}(\mathrm{III})$ ions yielded $\mathrm{V}$ (II). Reaction of various vanadium oxides $\left(\mathrm{V}_{2} \mathrm{O}_{3}, \mathrm{~V}_{2} \mathrm{O}_{4}\right.$ and $\mathrm{V}_{2} \mathrm{O}_{5}$ ) with $\mathrm{HCl}$ in chloride melts always produced oxygen containing vanadium(IV) species, $\mathrm{VOCl}_{4}{ }^{2-}$, in the melts. ${ }^{20}$ Electrochemical reduction of these vanadyl(IV) ions resulted in the formation of an insoluble oxygen-containing vanadium(III) phase, whereas the electrochemical oxidation did not alter the vanadium speciation in the melt.

In the present study electronic absorption spectroscopy was employed to study vanadium speciation in a variety of chloride melts. The EAS of vanadium species were resolved into individual bands and the spectroscopic parameters of vanadium complex ions were determined. X-ray diffraction (XRD) and Raman spectroscopy analysis of the quenched melts were also performed for deeper understanding vanadium coordination environment.

\section{Experimental}

The experiments were conducted in the melts based on $3 \mathrm{LiCl}-$ $2 \mathrm{KCl}$ and $\mathrm{NsCl}-2 \mathrm{CsCl}$ eutectic mixtures and $\mathrm{NaCl}-\mathrm{KCl}$ equimolar mixture between 450 and $750^{\circ} \mathrm{C}$. Electronic absorption spectra were recorded between 190 and $1100 \mathrm{~nm}$ using a custom-built set up based on an AvaSpec-2048FT-2-SPU (Avantes) fiber optic single beam spectrophotometer. The samples were contained in $1 \mathrm{~cm}$ path length optical silica cells heated in an optical furnace (Instron SFL model 1720). 

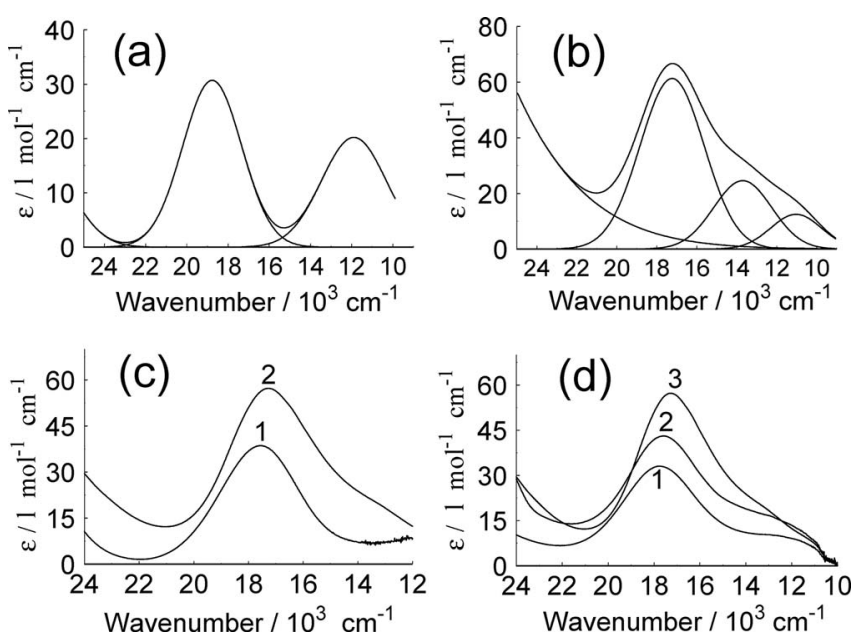

Figure 1. EAS of V(II) in alkali chloride melts. Spectra recorded in $3 \mathrm{LiCl}$ $2 \mathrm{KCl}$ melt at $450^{\circ} \mathrm{C}$ (a) and $\mathrm{NaCl}-2 \mathrm{CsCl}$ melt at $750^{\circ} \mathrm{C}$ (b) resolved into Gaussian bands. (c): EAS of V(II) in $\mathrm{NaCl}-2 \mathrm{CsCl}$ eutectic at $600^{\circ} \mathrm{C}$ (1) and $750^{\circ} \mathrm{C}(2)$. (d): EAS of $\mathrm{V}(\mathrm{II})$ at $750^{\circ} \mathrm{C}$ in $3 \mathrm{LiCl}-2 \mathrm{KCl}(1), \mathrm{NaCl}-\mathrm{KCl}$ (2) and $\mathrm{NaCl}-2 \mathrm{CsCl}(3)$ melts.

Optical part of the cell was attached to a silica tube with a side arm for connecting to an argon-vacuum line. The cell was closed by a rubber stopper holding necessary attachments (electrodes, tubes for introducing gases and for the melt sampling, etc.). The details of the spectroscopy experimental set-up were described previously. ${ }^{21}$ The measurements were performed in the following way. First, pure solvent salt was melted in the cell and intensity of the light passing though the cell and reaching the detector recorded. Then vanadium ions were introduced (e.g., by anodic dissolution of the metal, dissolution of vanadium chlorides, etc.) and intensity of the light passing through the sample measured. The absorption spectrum was then obtained as the logarithm of these two intensities ratio.

Commercially available alkali chlorides were dried under vacuum $(573 \mathrm{~K}, 3 \mathrm{~h})$ then heated above the melting point and treated with a mixture of $\mathrm{HCl}$ and $\mathrm{Cl}_{2}$ gases. Alkali chloride mixtures of the required compositions were prepared by fusing together individual alkali metal chlorides. Prior to use in spectroscopy measurements the mixtures thus prepared were subjected to the zone recrystallization under vacuum in a horizontal tube furnace. A furnace with a narrow hot zone moved along a silica tube containing the salt at a speed of approximately $1 \mathrm{~cm} / \mathrm{min}$ creating a moving liquid zone. This procedure was repeated 8 times for each batch of the salt. The salt mixtures were then kept in an argon filled dry box (MBraun Unilab).

Several methods of introducing vanadium ions into chloride melts were employed. Anhydrous vanadium trichloride $\left(99.9 \% \mathrm{VCl}_{3}\right.$, Aldrich) and dichloride ( $95 \% \mathrm{VCl}_{2}$, Aldrich) were used as solutes. In a separate series of experiments anodic dissolution of vanadium metal (99.6\%, Uralredmet) was employed. Reaction of vanadium oxides $\left(\mathrm{V}_{2} \mathrm{O}_{5}, 99+\%\right.$, Reachim; $\mathrm{V}_{2} \mathrm{O}_{4}, 99+\%$, Reahim; and $\mathrm{V}_{2} \mathrm{O}_{3}, 98 \%$, Aldrich) with hydrogen chloride in a molten solvent salt was used to prepare the melts containing vanadium oxo-chloro species.

After each experiment a sample of the melt was withdrawn using a silica capillary tube, and rapidly quenched under an inert atmosphere. Concentration of vanadium in the melt samples was determined by chemical analysis. Red-ox titration ${ }^{22}$ was used to determine the average oxidation state of vanadium.

\section{Results and Discussion}

Spectra of vanadium(II) ions.-Anodic dissolution of vanadium metal in chloride melts results in the formation of vanadium(II) ions. ${ }^{20}$ Spectra recorded during vanadium anodic dissolution showed a steady absorbance increase. The concentration of V(II) ions linearly increased with time, confirming that the system obeyed Beer's law. Examples of the spectra measured in different melts are presented in Figs. $1 \mathrm{a}$ and $1 \mathrm{~b}$. The spectrum recorded in the $3 \mathrm{LiCl}-2 \mathrm{KCl}$ eutectic at $450^{\circ} \mathrm{C}$ contained two well pronounced maxima around 12000 and $19000 \mathrm{~cm}^{-1}$, Fig. 1a. The low energy band was not so well pronounced in the EAS obtained in the same melt at higher temperatures $\left(600\right.$ and $\left.750^{\circ} \mathrm{C}\right)$ or in other melts $(\mathrm{NaCl}-\mathrm{KCl}$ and $\mathrm{NaCl}-2 \mathrm{CsCl})$. Instead, the spectra contained a shoulder at $12000-14000 \mathrm{~cm}^{-1}$, Fig. $1 \mathrm{~b}$. Resolution of the spectra into individual bands revealed that there were two bands under this shoulder. The results of analysis of V(II) EAS are listed in Tables I and II. The absorption bands at 1800019000 and $11000-12000 \mathrm{~cm}^{-1}$ originated from ${ }^{4} \mathrm{~A}_{2 \mathrm{~g}} \rightarrow{ }^{4} \mathrm{~T}_{1 \mathrm{~g}}(\mathrm{P})$ and ${ }^{4} \mathrm{~A}_{2 \mathrm{~g}} \rightarrow{ }^{4} \mathrm{~T}_{1 \mathrm{~g}}$ electronic transitions in the octahedral $\mathrm{VCl}_{6}{ }^{4-}$ complex ion $\left(\mathrm{d}^{3}\right.$-configuration). There was no evidence of any additional bands in the EAS recorded in the $3 \mathrm{LiCl}-2 \mathrm{KCl}$ eutectic at $450^{\circ} \mathrm{C}$. Increasing

Table I. Positions of the Absorption Bands in EAS of Vanadium Containing Melts Prepared by Vanadium Metal Anodic Dissolution.

Experimental Conditions

\begin{tabular}{|c|c|c|c|c|}
\hline Melt & Temperature, ${ }^{\circ} \mathrm{C}$ & Peak $1,{ }^{4} \mathrm{~A}_{2 \mathrm{~g}} \rightarrow{ }^{4} \mathrm{~T}_{1 \mathrm{~g}}(\mathrm{P}), \mathrm{VCl}_{6}{ }^{4-}$ & Peak $2,{ }^{4} \mathrm{~A}_{2 \mathrm{~g}} \rightarrow{ }^{4} \mathrm{~T}_{1 \mathrm{~g}}, \mathrm{VCl}_{6}{ }^{4-}$ & Peak $3,{ }^{4} \mathrm{~T}_{1} \rightarrow{ }^{4} \mathrm{~T}_{1}(\mathrm{P}), \mathrm{VCl}_{4}{ }^{2-}$ \\
\hline $3 \mathrm{LiCl}-2 \mathrm{KCl}$ & 450 & $18780(31.67)$ & $11900(22.26)$ & - \\
\hline $3 \mathrm{LiCl}-2 \mathrm{KCl}$ & 600 & $18260(38.64)$ & $11640(15.48)$ & $13890(2.89)$ \\
\hline $3 \mathrm{LiCl}-2 \mathrm{KCl}$ & 750 & $17670(42.15)$ & $11320(7.37)$ & $13010(4.59)$ \\
\hline $\mathrm{NaCl}-\mathrm{KCl}$ & 750 & $17730(48.35)$ & $11345(8.71)$ & $13860(17.62)$ \\
\hline $\mathrm{NaCl}-2 \mathrm{CsCl}$ & 600 & $17590(44.76)$ & 10905 (11.49) & $13560(3.98)$ \\
\hline $\mathrm{NaCl}-2 \mathrm{CsCl}$ & 750 & $17230(61.28)$ & $11030(12.50)$ & $13700(24.58)$ \\
\hline
\end{tabular}

Table II. Spectroscopic Parameters of $\mathrm{VCl}_{6}{ }^{4-}$ Ions.

Experimental Conditions

\begin{tabular}{|c|c|c|c|c|c|}
\hline & \\
\hline Melt & Temperature, ${ }^{\circ} \mathrm{C}$ & $\mathrm{Dq}, \mathrm{cm}^{-1}$ & $\mathrm{~B}, \mathrm{~cm}^{-1}$ & $\delta, \mathrm{kJ} / \mathrm{mol}$ & $\beta$ \\
\hline $3 \mathrm{LiCl}-2 \mathrm{KCl}$ & 450 & 762 & 521 & -109.4 & 0.68 \\
\hline $3 \mathrm{LiCl}-2 \mathrm{KCl}$ & 600 & 758 & 479 & -108.8 & 0.63 \\
\hline $3 \mathrm{LiCl}-2 \mathrm{KCl}$ & 750 & 743 & 447 & -106.7 & 0.58 \\
\hline $\mathrm{NaCl}-\mathrm{KCl}$ & 750 & 736 & 465 & -105.7 & 0.61 \\
\hline $\mathrm{NaCl}-2 \mathrm{CsCl}$ & 600 & 685 & 530 & -98.3 & 0.69 \\
\hline $\mathrm{NaCl}-2 \mathrm{CsCl}$ & 750 & 773 & 338 & -111.0 & 0.44 \\
\hline
\end{tabular}



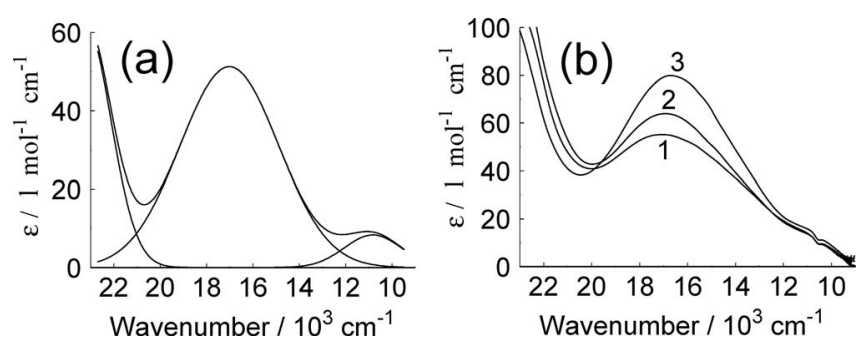

Figure 2. EAS of V(III) in alkali chloride melts. (a): Spectrum recorded in $\mathrm{NaCl}-2 \mathrm{CsCl}$ melt at $600^{\circ} \mathrm{C}$ resolved into Gaussian bands. (b): EAS of V(III) at $750^{\circ} \mathrm{C}$ in $3 \mathrm{LiCl}-2 \mathrm{KCl}(1), \mathrm{NaCl}-\mathrm{KCl}(2)$ and $\mathrm{NaCl}-2 \mathrm{CsCl}(3)$ melts.

temperature and/or the mean radius of the alkali metal cation of the solvent melt resulted in decreasing intensity of the second peak and appearance of a new band around $13500 \mathrm{~cm}^{-1}$. Previously, Gruen and McBeth proposed that there were two types of vanadium(II) ions in chloride melts with octahedral and tetrahedral coordination, and that increasing temperature favored the formation of the tetrahedral $\mathrm{VCl}_{4}{ }^{2-}$ species in $3 \mathrm{LiCl}-2 \mathrm{KCl}$ based melts. ${ }^{13,14}$ The band observed around $13500 \mathrm{~cm}^{-1}$ in the present study can reasonably be assigned to ${ }^{4} \mathrm{~T}_{1} \rightarrow{ }^{4} \mathrm{~T}_{1}(\mathrm{P})$ electronic transition in the tetrahedral $\mathrm{VCl}_{4}{ }^{2-}$ ion. Vanadium(II) was therefore always present as a mixture of six- and four-coordinated species at $600^{\circ} \mathrm{C}$ and above in all the melts studied here. The intensity of the band associated with $\mathrm{VCl}_{4}{ }^{2-}$ ion showed significant increase with temperature or alkali cation radius, Table II.

The intensity of the spectra increased with temperature, Fig. 1c, or radius of the alkali cations, Fig. 1d. Interestingly, the effect of temperature on the intensity of the peak corresponding to ${ }^{4} \mathrm{~A}_{2 \mathrm{~g}} \rightarrow{ }^{4} \mathrm{~T}_{1 \mathrm{~g}}(\mathrm{P})$ transition was greater than on the peak corresponding to ${ }^{4} \mathrm{~A}_{2 \mathrm{~g}} \rightarrow{ }^{4} \mathrm{~T}_{1 \mathrm{~g}}$ transition, Table I. Generally the absorption bands shifted toward lower energy upon increasing temperature or mean radius of the alkali metal cation. Ligand field splitting energy $D q$ in $\mathrm{VCl}_{6}{ }^{4-}$ ion decreases with temperature and cationic radius. Racah parameter $B$ increases with the radius of the cation resulting in increasing the nephelauxetic parameter $\beta$ characterizing the degree of "ionicity" of bonds in the complex ions. Ligand field stabilization energy $\delta$ of $\mathrm{VCl}_{6}{ }^{4-}$ ion decreases from $3 \mathrm{LiCl}-2 \mathrm{KCl}$ to $\mathrm{NaCl}-2 \mathrm{CsCl}$ based melts indicating increasing stability of the complex ion due to lowering polarizing effect of the outer sphere cations.

Attempts to prepare chloride melts by dissolving vanadium(II) chloride in molten alkali chlorides were not successful due to partial disproportionation of $\mathrm{VCl}_{2}$ or reaction with silica. The results of these experiments will be discussed below.

Spectra of vanadium(III) ions.-Vanadium(III) chloride dissolved in alkali chloride melts studied here yielding only V(III) ions. Analysis of the melts by red-ox titration confirmed that the average oxidation state of vanadium equaled to three. An example of V(III) EAS is presented in Fig. 2. The spectrum contains a clearly defined maximum around $17000 \mathrm{~cm}^{-1}$ and a shoulder around $11000-12000$ $\mathrm{cm}^{-1}$. The profile of EAS of vanadium(III) resembles that of vanadium(II). Resolution of the spectra into individual overlapping bands showed the presence of two absorption bands, Fig. 2a and the results obtained for various melts are listed in Table III. The absorption bands correspond to the ${ }^{3} \mathrm{~T}_{1 \mathrm{~g}} \rightarrow{ }^{3} \mathrm{~T}_{1 \mathrm{~g}}(\mathrm{P})$ and ${ }^{3} \mathrm{~T}_{1 \mathrm{~g}} \rightarrow{ }^{3} \mathrm{~T}_{2 \mathrm{~g}}$ electronic transitions in the octahedral $\mathrm{VCl}_{6}{ }^{3-}$ complex ion, $\mathrm{d}^{2}$-electron configuration. Varying melt composition did not alter the profile of the spectral curve and led only to increasing intensity with increasing radii of alkali cations, Fig. 2b. Molar absorption coefficient also increased with temperature and positions of the bands maxima shifted to the lower energies, Table III. Increasing average radius of the alkali metal cation in the melt also expectedly shifted the absorption bands to the lower energies due to decreasing polarizing effect of the second coordination sphere cations. Primary spectroscopic parameters listed in Table IV showed the same trends as for V(II) ions discussed above.

Similarly to vanadium(II), the octahedral-tetrahedral equilibrium was also proposed for vanadium(III) in $3 \mathrm{LiCl}-2 \mathrm{KCl}$ eutectic based melts. ${ }^{13,14}$ Careful analysis of the EAS recorded here between 450 $750^{\circ} \mathrm{C}$ in various melts did not reveal any additional absorption bands that could be attributed to $\mathrm{VCl}_{4}{ }^{-}$species. The EAS of tetrahedrally coordinated vanadium(III) were recorded in $\mathrm{CsAlCl}_{4}$ crystals at room temperature and contained four absorption bands at 15000, 10250, 9400 and $8250 \mathrm{~cm}^{-1} .{ }^{23}$ Increasing temperature normally shifts the band positions to the lower energies and here no bands at the positions appropriate for $\mathrm{VCl}_{4}{ }^{-}$ion could be justifiably resolved in the experimental spectra.

Vanadium(III) containing melts are very sensitive to oxygen. Reaction of $\mathrm{VCl}_{6}{ }^{3-}$ with oxygen results in the formation of soluble vanadyl species having the main absorption peak around $14000 \mathrm{~cm}^{-1}$. This peak could be mistaken for the absorption of the four-coordinated vanadium(III) chloro-species. The reaction of V(III) ions with oxygen will be discussed below.

Table III. Positions of the Absorption Bands in $\mathrm{VCl}_{6}{ }^{3-}$ Spectra Resolved into Individual Gaussian Bands.

Experimental Conditions

\begin{tabular}{cc}
\hline Melt & Temperature, ${ }^{\circ} \mathrm{C}$ \\
\hline $3 \mathrm{LiCl}-2 \mathrm{KCl}$ & 450 \\
$3 \mathrm{LiCl}-2 \mathrm{KCl}$ & 600 \\
$3 \mathrm{LiCl}-2 \mathrm{KCl}$ & 750 \\
$\mathrm{NaCl}-\mathrm{KCl}$ & 750 \\
$\mathrm{NaCl}-2 \mathrm{CsCl}$ & 600 \\
$\mathrm{NaCl}-2 \mathrm{CsCl}$ & 750
\end{tabular}

Band Position, $\mathrm{cm}^{-1}$ (Extinction Coefficient, $1 \cdot \mathrm{mol}^{-1} \cdot \mathrm{cm}^{-1}$ )

\begin{tabular}{cc}
\hline Peak $1,{ }^{3} \mathrm{~T}_{1 \mathrm{~g}} \rightarrow{ }^{3} \mathrm{~T}_{1 \mathrm{~g}}(\mathrm{P})$ & Peak $2,{ }^{3} \mathrm{~T}_{1 \mathrm{~g}} \rightarrow{ }^{3} \mathrm{~T}_{2 \mathrm{~g}}$ \\
$17890(29.35)$ & $11040(5.00)$ \\
$17490(44.10)$ & $11010(5.24)$ \\
$16930(55.27)$ & $10980(5.49)$ \\
$16770(63.81)$ & $10890(6.67)$ \\
$17010(51.25)$ & $10820(6.33)$ \\
$16570(78.86)$ & $10770(7.33)$
\end{tabular}

Table IV. Spectroscopic Parameters of $\mathrm{VCl}_{6}{ }^{3-}$ Ions.

Experimental Conditions

\begin{tabular}{ccccr}
\hline Melt & Temperature, ${ }^{\circ}$ & $\mathrm{C}$ & $\mathrm{Bq}, \mathrm{cm}^{-1}$ & $\delta, \mathrm{kJ} / \mathrm{mol}$ \\
\cline { 3 - 5 } 3LiCl-2KCl & 450 & 1204 & 523 & -103.3 \\
3LiCl-2KCl & 600 & 1198 & 496 & -103.1 \\
3LiCl-2KCl & 750 & 1190 & 457 & -102.9 \\
NaCl-KCl & 750 & 1180 & 452 & -102.1 \\
NaCl-2ClCl & 600 & 1175 & 475 & -101.3 \\
NaCl-2CsCl & 750 & 1166 & 446 & -100.9
\end{tabular}



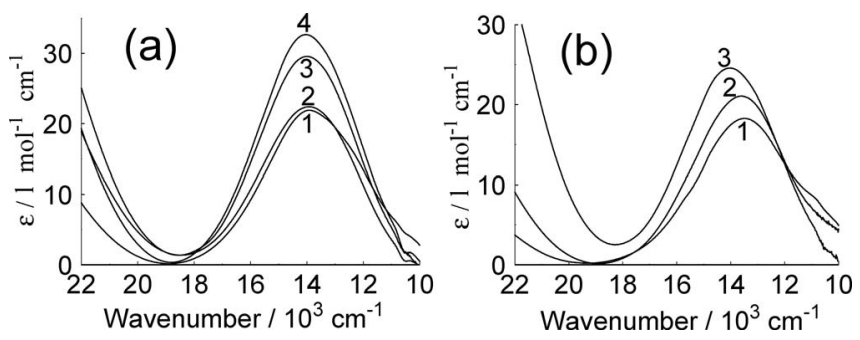

Figure 3. (a): EAS of V(IV) species in alkali chloride melts at $600^{\circ} \mathrm{C}(1)$ and $750^{\circ} \mathrm{C}(2-4)$. Melt were $\mathrm{NaCl}-2 \mathrm{CsCl}(1$ and 2$), 3 \mathrm{LiCl}-2 \mathrm{KCl}(3)$ and $\mathrm{NaCl}-$ $\mathrm{KCl}$ (4). (b): Effect of temperature on EAS of V(IV) species in $3 \mathrm{LiCl}-2 \mathrm{KCl}$ based melts, $450^{\circ} \mathrm{C} \mathrm{(1),} 600^{\circ} \mathrm{C} \mathrm{(2)} \mathrm{and} 750^{\circ} \mathrm{C}$ (3). Melts were obtained by reacting vanadium oxides with $\mathrm{HCl}$.

Spectra of vanadium(IV) ions.-All attempts to record EAS of $\mathrm{V}(\mathrm{IV})$ chloro-species in alkali chloride melts did not produce satisfactory results due to high volatility of vanadium tetrachloride (b.p. $148.5^{\circ} \mathrm{C}$ ). Vanadium(IV) forms a stable $\mathrm{VO}^{2+}$ (vanadyl) cation and therefore it appears that only oxochloro-species of V(IV) can be stabilized in the high temperature chloride melts. Reaction of all common vanadium oxides, i.e., $\mathrm{V}_{2} \mathrm{O}_{3}, \mathrm{~V}_{2} \mathrm{O}_{4}$ and $\mathrm{V}_{2} \mathrm{O}_{5}$, with hydrogen chloride in molten alkali chlorides resulted in formation of vanadium(IV)containing melts irrespectively of the starting oxide. ${ }^{20}$ In the visible region the absorption spectra contained a single band around 14000 $\mathrm{cm}^{-1}$, Figs. 3, 4. Increasing temperature resulted in increasing intensity of this band in $3 \mathrm{LiCl}-2 \mathrm{KCl}$ eutectic based melts, Fig. $3 \mathrm{~b}$. However, in $\mathrm{NaCl}-2 \mathrm{CsCl}$ eutectic the behavior was the opposite and intensity of the main band in the spectrum did not change with temperature, Fig. 3a. The intensity of this band in the $\mathrm{NaCl}-2 \mathrm{CsCl}$ based melt was also lower than in the other systems studied, Fig. 3a. Such anomalous behavior can indicate that the structure of vanadium(IV) complex ions in $\mathrm{NaCl}-2 \mathrm{CsCl}$ eutectic is different from that in cesiumfree $3 \mathrm{LiCl}-2 \mathrm{KCl}$ and $\mathrm{NaCl}-\mathrm{KCl}$ melts.

Pioneering studies in chloride and thiocyanate melts described vanadyl species as four- or six-coordinated with one oxygen and three or five melt anions. ${ }^{13-16}$ Resolution of the spectra recorded in the present study into individual bands showed that at $750^{\circ} \mathrm{C}$ in all the melts studied there was only one band hidden under the absorption maximum in the visible region of the spectrum, Table V. At lower temperatures the same maximum could be satisfactorily resolved only in two bands. Examples of the resolved spectra are shown in Fig. 4.

There are two main views on the coordination of vanadyl chlorocomplexes. Six-coordinated $\mathrm{VOCl}_{5}{ }^{3-}$ ion (distorted octahedron, $C_{4 \mathrm{v}}$ symmetry) was characterized in crystalline matrixes. ${ }^{24,25}$ Electronic absorption spectra of this species exhibited a maximum around $15500 \mathrm{~cm}^{-1}$ and a shoulder around $16200 \mathrm{~cm}^{-1}$ due to ${ }^{2} \mathrm{~B}_{2} \rightarrow{ }^{2} \mathrm{E}$ and ${ }^{2} \mathrm{~B}_{2} \rightarrow{ }^{2} \mathrm{~B}_{1}$ electronic transitions, respectively. However, modeling the electronic structure of $\mathrm{VOCl}_{5}^{3-}$ by the SCF-MS-X $\alpha$ method showed that energies of the corresponding transitions should be equal to 8230 and $13060 \mathrm{~cm}^{-1}$. ${ }^{26}$

More recent works advocated five-coordinated $\mathrm{VOCl}_{4}{ }^{2-}$ ion (square pyramidal, $\mathrm{C}_{4 \mathrm{v}}$ symmetry) for chloride systems. Such species were characterized by EPR and visible spectroscopy in $\left[\mathrm{Et}_{4} \mathrm{~N}\right]_{2}\left[\mathrm{VOCl}_{4}\right]$ crystals, ${ }^{27} \mathrm{CsCl}$ crystals containing $\mathrm{Cs}_{2} \mathrm{VOCl}_{4},{ }^{28}$ concentrated hydrochloric acid solutions of $\mathrm{Cs}_{2} \mathrm{VOCl}_{4}$ and $\mathrm{Rb}_{2} \mathrm{VOCl}_{4}{ }^{29}$ solutions of $\left[\mathrm{Et}_{4} \mathrm{~N}_{2}\left[\mathrm{VOCl}_{4}\right]\right.$ in methyl cyanide ${ }^{29}$ and acetic acid, ${ }^{30}$ and solutions of $\left[\mathrm{Et}_{4} \mathrm{~N}\right]_{2}\left[\mathrm{VOCl}_{4}\right]$ and $[\mathrm{emim}]_{2}\left[\mathrm{VOCl}_{4}\right]$ in the basic [emim]Cl- $\mathrm{AlCl}_{3}$ ionic liquid. ${ }^{31}$ Spectral curves reported in these studies contained a high intensity maximum at 13000-14300 $\mathrm{cm}^{-1}$, and in some cases a weak overlapping band at 11600-12100 $\mathrm{cm}^{-1}$. Moreover the presence of $\mathrm{VOCl}_{4}{ }^{2-}$ is proved by EXAFS. ${ }^{31}$

Therefore we suppose that in alkali chloride melts vanadyl is likely coordinated to four chloride ions forming $\mathrm{VOCl}_{4}{ }^{2-}$. Maxima in the absorption spectra observed at $13540-13980 \mathrm{~cm}^{-1}$ and $9900-10820$ $\mathrm{cm}^{-1}$ originate from ${ }^{2} \mathrm{~B}_{2} \rightarrow{ }^{2} \mathrm{~B}_{1}$ and ${ }^{2} \mathrm{~B}_{2} \rightarrow{ }^{2} \mathrm{E}$ electronic transitions, respectively. Such interpretation, however, does not explain changes
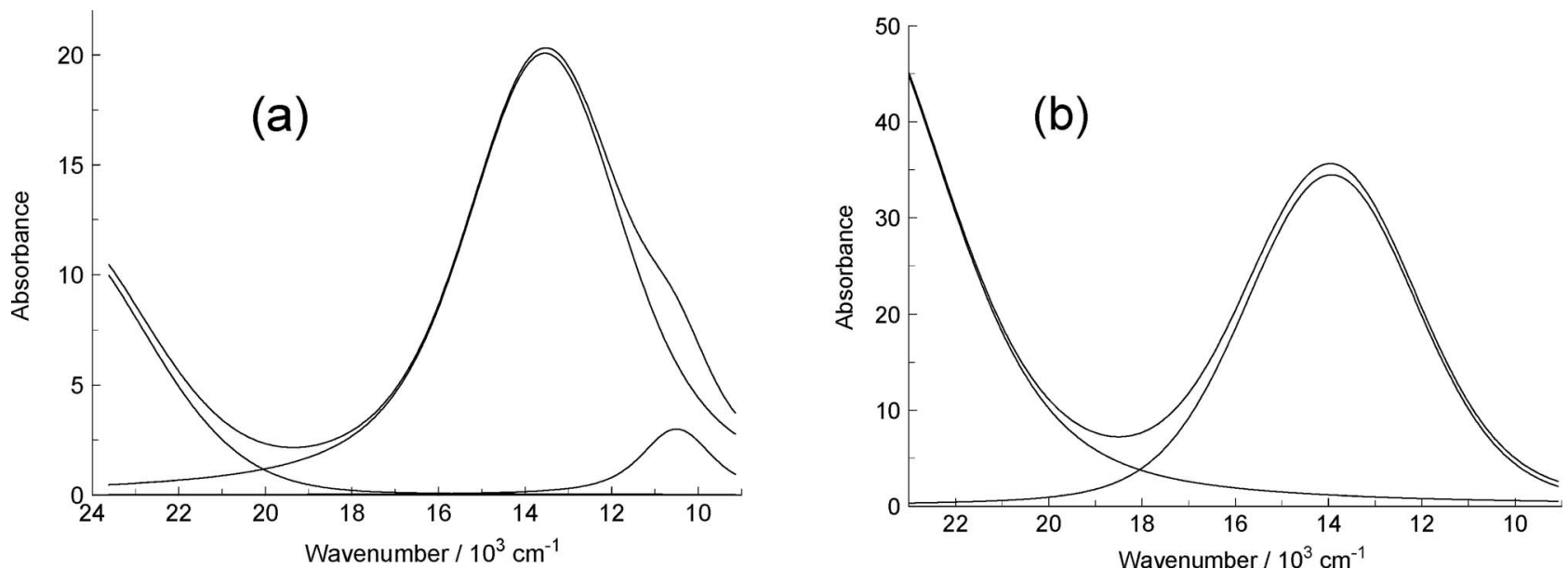

Figure 4. EAS of $\mathrm{V}(\mathrm{IV})$ in $3 \mathrm{LiCl}-2 \mathrm{KCl}$ melt at $450^{\circ} \mathrm{C}$ (a) and $750^{\circ} \mathrm{C}$ (b) resolved into individual bands.

Table V. Positions of the Absorption Bands in EAS of $\mathrm{VO}^{2+}$ - containing Melts and Spectroscopic Parameters of V(IV) Oxychloride Species.

\begin{tabular}{|c|c|c|c|c|}
\hline \multicolumn{2}{|c|}{ Experimental Conditions } & \multicolumn{2}{|c|}{$\begin{array}{c}\text { Band Position, } \mathrm{cm}^{-1} \\
\left(\text { Extinction Coefficient, } 1 \cdot \mathrm{mol}^{-1} \cdot \mathrm{cm}^{-1} \text { ) }\right.\end{array}$} & \multirow{2}{*}{$\begin{array}{l}\text { Ligand Field Splitting Energy } \\
\qquad \mathrm{Dq}, \mathrm{cm}^{-1}\end{array}$} \\
\hline Melt & Temperature, ${ }^{\circ} \mathrm{C}$ & Peak $1,{ }^{2} \mathrm{~B}_{2} \rightarrow{ }^{2} \mathrm{~B}_{1}$ & Peak $2,{ }^{2} \mathrm{~B}_{2} \rightarrow{ }^{2} \mathrm{E}$ & \\
\hline $3 \mathrm{LiCl}-2 \mathrm{KCl}$ & 450 & $13540(20.08)$ & $10500(3.00)$ & 1354 \\
\hline $3 \mathrm{LiCl}-2 \mathrm{KCl}$ & 600 & $13680(22.98)$ & $9900(2.63)$ & 1368 \\
\hline $3 \mathrm{LiCl}-2 \mathrm{KCl}$ & 750 & $13940(34.47)$ & - & 1394 \\
\hline $\mathrm{NaCl}-\mathrm{KCl}$ & 750 & $13980(35.51)$ & - & 1398 \\
\hline $\mathrm{NaCl}-2 \mathrm{CsCl}$ & 600 & $13850(23.60)$ & $10820(2.36)$ & 1385 \\
\hline $\mathrm{NaCl}-2 \mathrm{CsCl}$ & 750 & $13920(24.83)$ & - & 1392 \\
\hline
\end{tabular}




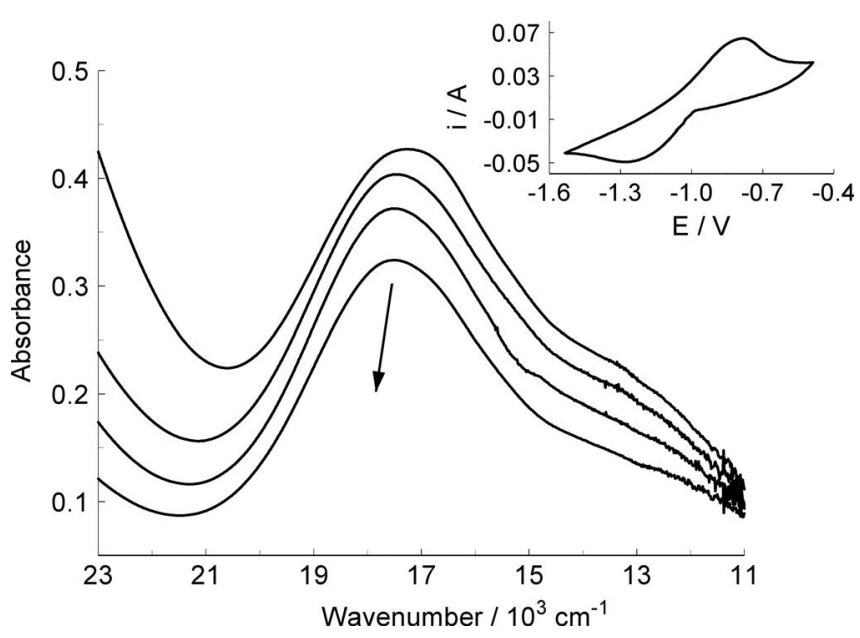

Figure 5. EAS recorded during cathodic reduction of $\mathrm{V}(\mathrm{III})$ in $\mathrm{NaCl}-\mathrm{KCl}$ melt at $750^{\circ} \mathrm{C}$ and potential of $-1.35 \mathrm{~V}$ vs. $\mathrm{Cl}_{2} / \mathrm{Cl}^{-}$reference electrode. Insert shows a cyclic voltammogram of the starting melt and arrow shows the direction the spectra changed.

the spectra with temperature. It is possible that the "disappearance" of the low energy band at lower temperatures is caused by its shift to the higher energy where it is completely masked by the intense band around $13500-14000 \mathrm{~cm}^{-1}$. From the other side, it cannot be excluded that the band at ca. $10000-11000 \mathrm{~cm}^{-1}$ is associated with another coordination form of vanadyl ion.

Spectroscopic study of red-ox reactions in vanadium containing melts. - Vanadium ions in chloride melts have distinct absorption spectra and therefore electronic absorption spectroscopy offers a convenient tool for studying reactions in vanadium containing melts. Anodic dissolution of vanadium metal was considered above in the discussion of V(II) spectra. Some red-ox processes involving soluble vanadium species are discussed below.

Vanadium(II)-containing alkali chloride melts could not be obtained by dissolution of vanadium(II) chloride. Vanadium dichloride added to molten alkali chlorides underwent partial disproportionation yielding V(III) chloro-species and vanadium metal. Average oxidation state of vanadium in the quenched melt samples was always above two, and vanadium concentration was significantly lower than expected from the amount of $\mathrm{VCl}_{2}$ added. The resulting melt contained a mixture of $\mathrm{V}$ (II) and V(III) ions and the absorption spectrum represented a superposition of $\mathrm{VCl}_{6}{ }^{4-}$ and $\mathrm{VCl}_{6}{ }^{3-}$ absorption bands.

Vanadium(III) chloro-ions can be cathoducally reduced to vanadium(II). A cyclic voltammogram recorded in a V(III)-containing melt had one cathodic and one corresponding anodic wave around -1.25 $\mathrm{V}$ and $-0.8 \mathrm{~V}$ vs. $\mathrm{Cl}^{-} / \mathrm{Cl}_{2}$ reference electrode, cf. the insert in Fig. 5 . These waves are associated with $\mathrm{V}(\mathrm{III}) / \mathrm{V}$ (II) reduction/oxidation process. Cathodic reduction of $\mathrm{V}$ (III) was performed at $-1.35 \mathrm{~V}$ on a glassy carbon electrode and was followed spectroscopically, Fig. 5. In the course of the reduction the intensity of the main absorption band decreased and the low-energy edge of the charge transfer band was shifted to the higher energy. The position of the absorption maximum in the EAS also shifted to the higher energy. Final absorption spectrum corresponded to vanadium(II) ions but there was no isosbestic point, indicating that the total vanadium concentration in the melt decreased. Vanadium(II) chloro-species can undergo disproportionation or react with silica likely resulting in formation of lower oxidation state silica oxides. Both these processes can account for decreasing vanadium concentration in the melt. The presence of excess vanadium metal during anodic dissolution slowed the disproportionation reaction and shifted the equilibrium toward vanadium (II). Thus vanadium(II) chloro-species, $\mathrm{VCl}_{6}{ }^{4-}$, can be formed in the melts as a result of cathodic reduction of vanadium(III) ions but the quantitative reduction is not possible, at least in silica cells.

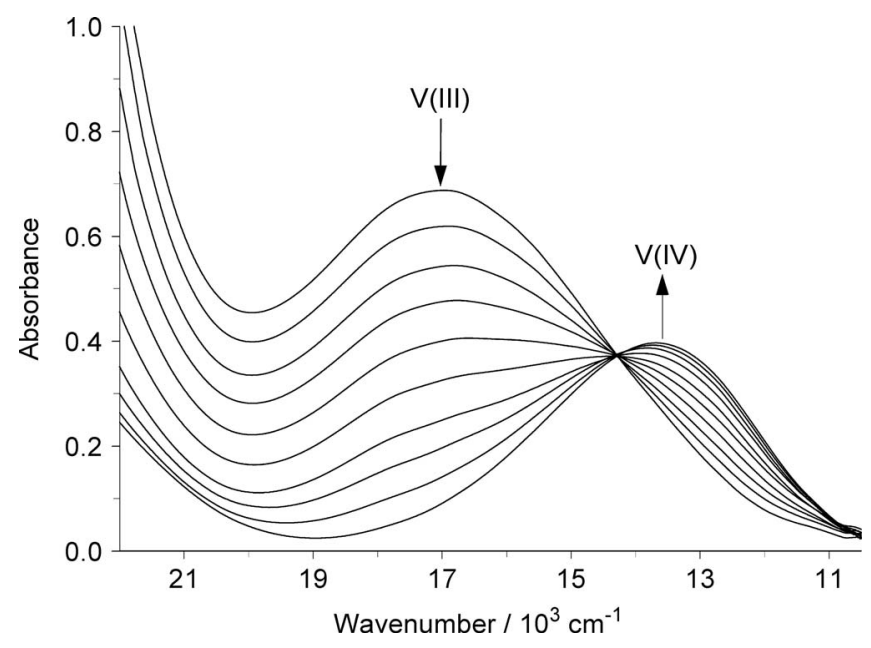

Figure 6. Evolution of $\mathrm{VCl}_{6}{ }^{3-} \mathrm{EAS}$ in $\mathrm{NaCl}-\mathrm{KCl}$ based melt exposed to the air, $750^{\circ} \mathrm{C}, 0.05 \mathrm{wt} \%$ vanadium. Arrows show the direction the spectra changed, vanadium oxidation states responsible for the absorption identified on the plot.

Oxidation of vanadium(III) by oxygen mentioned above leads to the formation of vanadyl ions and proceeds quantitatively. Fig. 6 shows how the $\mathrm{VCl}_{6}{ }^{3-}$ spectra in $\mathrm{NaCl}-\mathrm{KCl}$ melt changed when the melt was exposed to the air. Chemical analysis showed that the total concentration of vanadium in the melt did not change, and this was also confirmed by the presence of the isosbestic point in the spectra. The oxidation state of vanadium in the melt increased from 3.0 to 3.9, indicating that nearly all V(III) was oxidized to V(IV).

Vanadium(IV)-containing melts can also react with oxygen. When vanadium(IV)-containing melts were oxidized by air, the intensity of the absorption band around $14000 \mathrm{~cm}^{-1}$ gradually decreased and the peak eventually disappeared. The resulting product in this case is likely a vanadate species containing vanadium in the oxidation state +5 . The presence of an isosbestic point in the spectra (Fig. 7) showed that the total concentration of vanadium in the melt did not change.

Cyclic voltammograms measured on a glassy carbon electrode in vanadyl-containing melts exhibited only a single cathodic wave corresponding to the irreversible reduction, cf. the insert in Fig. 8. Potentiostatic cathodic reduction at $-1.3 \mathrm{~V}$ (vs. the chlorine reference electrode) resulted in decreasing absorbance in the entire spectral

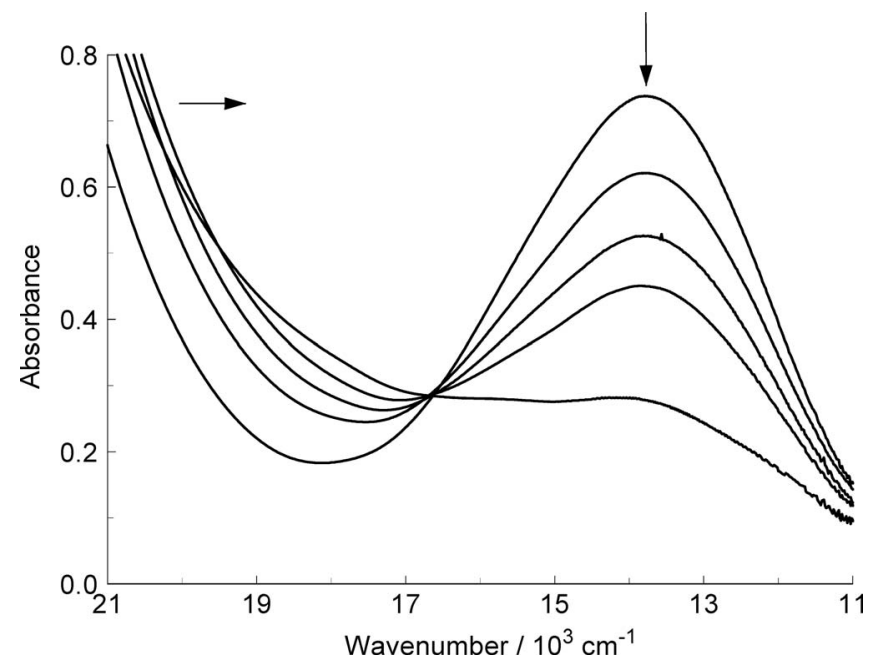

Figure 7. EAS recorded upon reaction of $\mathrm{NaCl}-\mathrm{KCl}$ melt containing vanadyl ions with oxygen from the air, $750^{\circ} \mathrm{C}$. Arrows show the direction the spectra changed. 


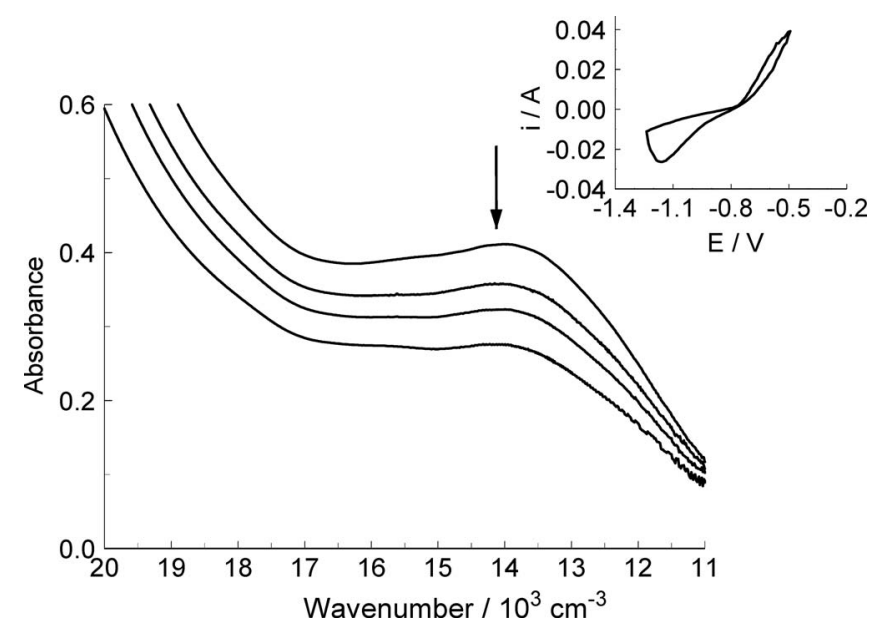

Figure 8. EAS recorded during potentiostatic cathodic reduction of vanadyl species in $\mathrm{NaCl}-\mathrm{KCl}$ melt at $750^{\circ} \mathrm{C}$ potential of $-1.3 \mathrm{~V}$ vs. $\mathrm{Cl}_{2} / \mathrm{Cl}^{-}$reference electrode. Insert shows a cyclic voltammogram of the starting melt and arrow shows the direction the spectra changed.

region considered (Fig. 8) and formation of an insoluble phase. Formation of the precipitate confirmed that in alkali chloride melts there is no soluble oxygen-containing vanadium species where vanadium would be in the oxidation state below +4 . The anodic part of the cyclic voltammograms did not contain any clear waves. An attempt to perform an oxidative electrolysis at $-0.5 \mathrm{~V}$ vs. chlorine reference electrode did not result in the formation of new species in the melt and the spectral picture remained unchanged. Therefore it is likely that the potential of $\mathrm{VO}^{3+} / \mathrm{VO}^{2+}$ red-ox couple is more positive than that of $\mathrm{Cl}_{2} / \mathrm{Cl}^{-}$.

\section{Conclusions}

Vanadium speciation in alkali chloride melts was studied employing high temperature electronic absorption spectroscopy. Anodic dissolution of metallic vanadium produced vanadium(II) species. Increasing temperature and the mean radius of the solvent salt cation resulted in changes of $\mathrm{V}$ (II) electronic spectra as a result of shifting $\mathrm{VCl}_{6}{ }^{4-} \leftrightarrow \mathrm{VCl}_{4}{ }^{2-}$ octahedral-tetrahedral equilibrium toward the fourcoordinated complex ions. Octahedral $\mathrm{VCl}_{6}{ }^{3-}$ complex ion is the only soluble V(III) species in fused chlorides. No evidence of other coordination for V(III) was obtained. Cathodic reduction of vanadium(III) produced vanadium(II) ions. Oxidation of $\mathrm{VCl}_{6}{ }^{3-}$ by oxygen or chlorination of $\mathrm{V}_{2} \mathrm{O}_{5}, \mathrm{~V}_{2} \mathrm{O}_{4}$ or $\mathrm{V}_{2} \mathrm{O}_{3}$ by hydrogen chloride produced soluble vanadyl-based complexes. The results obtained here indicated that the coordination environment around vanadyl-based species depended on temperature. Cathodic reduction of vanadyl species led to the formation of an insoluble oxygen-containing vanadium(III) phase, whereas anodic oxidation did not affect vanadium speciation in the melt. Oxidation of vanadyl ions by oxygen produced vanadate $(\mathrm{V})$ anions.

\section{References}

1. G. K. Gupta and N. Krisnnamurthy, Extractive metallurgy of vanadium, Elsevier Science, Amsterdam (1992).

2. M. Peters, J. Kumpfert, C. H. Ward, and C. Leyens, Adv. Eng. Mater, 5(6), 419 (2003).

3. R. Lagneborg, T. Siwecki, S. Zajac, and B Hutchinson, Scand. J. Metallurgy, 28(5), 186 (1999).

4. T. Muroga, T. Nagasaka, K Abe, V. M. Chernov, H. Matsui, D. L. Smith, Z.-Y. Xu, and S. J. Zinkle, J. Nucl. Mater, 307-311(1) Suppl., 547 (2002).

5. B. M. Klein, L. L. Boyer, D. A. Papaconstantopoulos, and L. F. Mattheiss, Phys. Rev. $B, 18(12), 6411$ (1978).

6. S. Kumar, A. Jain, T. Ichikawa, Y. Kojima, and G. K. Dey, Renewable and Sustainable Energy Reviews, 72, 791 (2017).

7. O. N. Carlson, F. A. Schmidt, and W. E. Krupp, J. Metals, 18(3), 320 (1966).

8. R. Kieffer, H. Bach, and H. Lutz, Metall, 21(1), 19 (1967).

9. T. T. Campbell, J. L. Schaller, and F. E. Block, Metallurg. Trans., 4(1), 237 (1973).

10. K. K. Schulze, O. N. Carlson, and M. Uz, in Klaus Schulze Symp. Process. Appl. High Purity Refract. Met. Alloys, Proc. Symp., p. 229, Warrendale (2005)

11. G. Hurrington and B. R. Sundheim, Ann. N. Y. Acad. Sci., 79, 950 (1960)

12. R. Molina, Bull. Soc. Chim. Fr., 301 (1961).

13. D. M. Gruen and R. L. McBeth, J. Phys. Chem., 66, 57 (1962).

14. D. M. Gruen and R. L. McBeth, Pure Appl. Chem., 6, 23 (1963).

15. H. C. Egghart, J. Phys. Chem., 73, 4014 (1969).

16. D. H. Kerridge and M. Mosley, J. Chem. Soc., A., 2211 (1969).

17. B. D. Vasin, S. V. Maslov, and I. B. Polovov, Rasplavy, (2), 51 (1999).

18. I. B. Polovov, V. A. Volkovich, S. A. Shipulin, S. V. Maslov, A. A. Khokhryakov, B. D. Vasin, T. R. Griffiths, and R. C. Thied, J. Mol. Liquids, 105, 105 (2003).

19. B. D. Vasin, I. B. Polovov, V. A. Volkovich, T. R. Griffiths, and A. V. Berezin, in Molten Salts XIV/2004, R. A. Mantz, P. C. Trulove, H. C. De Long, G. R. Stafford, M. Hagiwara, and D. A. Costa, Editors, PV 2004-24, p. 261, The Electrochemical Society, Pennington, NJ (2006)

20. M. V. Chernyshov, I. B. Polovov, V. A. Volkovich, O. I. Rebrin, B. D. Vasin, K. V. Vinogradov, and T. R. Griffiths, ECS Trans, 33(7), 287 (2010).

21. V. A. Volkovich, I. May, J. M. Charnock, and B. Lewin, Phys. Chem. Chem. Phys., 4, 5753 (2002)

22. B. D. Vasin, S. V. Maslov, V. A. Volkovich, I. B. Polovov, S. A. Kazakov, and O. I. Rebrin, in Proc. 7-th Int. Symp. Molten Salts Chem. Techn., vol. 1, P. Taxil, C. Bessada, M. Cassir, and M. Gaune-Escard, Editors, p. 335, Toulouse (2005).

23. D. M. Gruen and R. Gut, Nature, 190(4777), 713 (1961).

24. R. A. D. Wentworth and T. S. Piper, J. Chem. Phys., 41, 3884 (1964)

25. K. DeArmond, B. B. Garrett, and H. S. Gutowsky, J. Chem. Phys., 42, 1019 (1965).

26. K. K. Sunil, J. F. Harrison, and M. T. Rogers, J. Chem. Phys., 76, 3087 (1982).

27. D. Collison, B. Gahan, C. D. Garner, and F. E. Mabbs, J. Chem. Soc., Dalton Trans., (4), 667 (1980).

28. G. Elbers and G. Lehmann, Z. Naturforsch., 40a, 511 (1985).

29. J. E. Drake, J. E. Vekris, and J. S. Wood, J. Chem. Soc., A., 345 (1969)

30. H. Kon and N. E. Sharpless, J. Chem. Phys., 70, 105 (1966).

31. A. J. Dent, A. Lees, R. J. Lewis, and T. Welton, J. Chem. Soc., Dalton Trans., (13), 2787 (1996) 